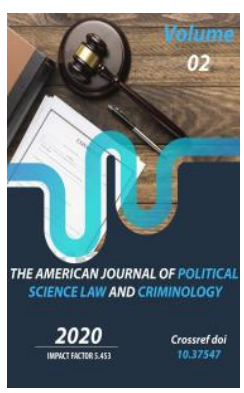

\title{
The Adoption Of The Election Code Is A Bold Step In The Direction Of "New Uzbekistan - New Elections"
}

\author{
Oybek Turgunov
}

PhD, Assistant-Professor, Head Of The Department Of The Military Technical Institute Of The National Guard Of The Republic Of Uzbekistan

Copyright: Original content from this work may be used under the terms of the creative commons attributes 4.0 licence.

\section{ABSTRACT}

The article describes the adoption of the electoral code in Uzbekistan, its compliance with generally recognized international democratic standards, the improvement of national electoral legislation in Uzbekistan, new rules on elections, proposals and recommendations of international organizations.

\section{KEYWORDS}

Code, elections, election commissions, international organizations, action strategies, international standards.

\section{INTRODUCTION}

Elections have played a central role in the development of democracies and in the system of political rights of citizens as an important constitutional and legal institution. It is through this institution that citizens have the opportunity to govern the state and society, directly or through their elected representatives. After all, the core of any democratic society is free and fair elections.
During the years of independence, holding democratic elections in our country has become an important socio-political tradition. In particular, the parliamentary elections were held twelve times - on December 25, 1994, December 10, 1999, December 26, 2004, December 27, 2009, December 21, 2014, December 22, 2019, December 29, 1991, January 9, 2000, 2015. The national presidential 
elections of March 29, 1995, the referendums of March 26, 1995 and January 27, 2002, as well as the early presidential elections of December 4, 2016 became the basis for the institutional formation and strengthening of the national electoral system of Uzbekistan. Therefore, as noted by the President of the Republic of Uzbekistan Shavkat Mirziyoyev, "in the electoral process, first of all, our worldview, political and legal culture, our civic position will be reflected once again" [1].

\section{METHODS}

The importance of our national legislation and electoral practice in ensuring that the process of preparation and conduct of elections in our country fully meets international norms and democratic principles is incomparable. Therefore, in his first Address to the Oliy Majlis on December 22, 2017, the President set the task to develop and adopt the Electoral Code of the Republic of Uzbekistan. Also, on November 6, 2018, the Presidential Decree "On organizational measures to improve the activities of the Central Election Commission of the Republic of Uzbekistan" approved the "Program of measures to improve the electoral legislation and law enforcement practices". Also, the Presidential Decree "On measures to introduce modern information and communication technologies in the electoral process" adopted on October 4, 2018, was a logical continuation of the ongoing democratic reforms in the field of electoral legislation. It should be noted that the creation of the Electoral Code of the Republic of Uzbekistan is directly related to the current state of electoral legislation and practice, and secondly, due to the fact that the adopted laws and a number of bylaws are not integrated. Third, in all five existing Laws, almost the same norms related to the suffrage of citizens are repeated. Therefore, the large number of electoral laws also posed certain difficulties in their application by citizens.

\section{RESULTS AND DISCUSSIONS}

The Electoral Code provides for a single, transparent and effective approach to the electoral process, codification of electoral laws and regulations in accordance with international norms and standards and the requirements of best international practice [2]. This, in turn, resulted in the adoption of this Code, five comprehensive laws providing for amendments and additions, and 17 laws on amendments to them. Its preparation and development is based primarily on our national election legislation and electoral practice, the Constitution of the Republic of Uzbekistan, 5 election laws and about 40 by laws of the Central Election Commission, as well as our practical experience in elections over the years of independence foreign experiments were used.

During the preparation of the Code, the electoral codes and laws of more than 50 countries around the world were studied, in particular, France, the Netherlands, Canada, Italy, Sweden, Belgium, Poland, Albania, Belarus, Azerbaijan. International election standards and democratic principles as well as. More than 10 international election documents have been thoroughly analyzed and their main ideas and standards have been incorporated into the Electoral Code of the Republic of Uzbekistan. At the same time, the Code was submitted to international organizations for independent international expertise. Recommendations of the OSCE Office for Democratic Institutions and Human Rights (ODIHR), as well as conclusions and opinions 
from the Venice Commission of the Council of Europe and the Executive Committee of the Commonwealth of Independent States (CIS) were received. If we analyze these aspects from a scientific point of view, the changes that took place in the suffrage of the Republic of Uzbekistan during the years of independence can be assessed as a systemic modernization. However, it should be noted that the process of formation of the electoral system of Uzbekistan is still far from complete. Indeed, the possibilities for further development of suffrage in the creation of an optimal legal regime that fully meets the requirements for the consistent establishment of the basis of representation at all levels of the people's government are not over. This trend is typical not only for Uzbekistan, but also for other most developed countries. It is this aspect that distinguishes complex and multifaceted electoral processes from other stable legal processes. Imagine that if there was a ranking of popularity among the branches of our national legal system, suffrage would undoubtedly occupy one of the highest positions in it, because it is recognized and recognized among the public and social strata. That is why there are serious opinions among the jurists that the science of constitutional law, which forms a complex institution of electoral law, has already gone beyond the direct sphere of influence and is becoming a legal system in the form of a higher structure. In his Address to the Oliy Majlis on January 24, 2020, the President called 2020 the Year of Science, Enlightenment and Development of the Digital Economy.

Today, a large-scale work is being carried out to prioritize the development and reform of the areas identified in the name of the year. In particular, consistent work has been done on the basis of the plan "Measures to further improve the system of formation and use of a single electronic voter list", approved by the Presidential Decree "On measures to introduce modern information and communication technologies in the electoral process." In this sense, it is no exaggeration to say that the elections held on December 22, 2019 were held in a completely new format, not only in terms of legislation, but also in terms of technical and technological. The new election code contains not only a set of scattered norms, but also a number of innovations, rules and procedures. First, the institute of quotas for representatives of the Ecological Movement of Uzbekistan was abolished. Second, the procedure for nominating candidates for district (city) Councils of People's Deputies by citizens' self-government bodies has been abolished. Third, the formation of a single electronic voter list is regulated by the Code. Fourth, the concept of a "ballot paper" was removed through the introduction of a single ballot. Fifth, the procedure for consideration of appeals of individuals and legal entities on election issues has been introduced. Sixth, it was stipulated that voters could sign in support of one or more candidates or parties during the signature collection process. Seventh, voting time was set from 08:00 to 20:00. In addition, a number of new rules related to the electoral process have been introduced. In particular, the submission of proposals on candidates for membership in the precinct election commission by citizens' self-government bodies, public associations; the regulation on the procedure for electing members of the Senate of the Oliy Majlis was repealed, and the issue of electing members of the Senate at the level of the Code was introduced. New requirements have been introduced for 
members of election commissions. It was established that close relatives and proxies of candidates, as well as persons directly subordinate to candidates may not be members of the election commission.

In addition, norms restricting the participation of persons who have committed low-risk and less serious crimes in elections have been removed. When forming constituencies, the maximum permissible deviation of the number of voters in constituencies shall not exceed 10\%. At the same time, special requirements were set for the members of the Central Election Commission and their status was equated with the deputies of the Legislative Chamber and the Senate of the Oliy Majlis. In short, the Electoral Code, developed at the initiative of the President, reflects the democratic principles of openness, transparency, fairness and impartiality, has a topical content and great legal, social and political significance. Emphasizing the sociopolitical status of suffrage and its independent place in the public-legal system, it can be said that in the future suffrage is likely to be formed as an independent branch of public law. This phenomenon is not limited to the clarification of the provisions of the electoral law, but also includes the formation of new elements in the system of suffrage. Therefore, the next stage of development of the electoral system may be associated with the formation of a multielectoral system in our country. Indeed, the fact that we are following the path of a multiparty system brings together the ways of systematically forming ideologically closely related institutions of interdependence.

\section{CONCLUSION}

Multiple elections are a form of indirect elections, in which a permanent representative body, elected on the basis of direct suffrage, acts as an expression of the will of the electorate. The powers of this body include the right to elect another body or official. Multiple elections are not new for the legal system of our country. Elements of multi-level elections can also be found in the legislation of modern Uzbekistan. It is widely acknowledged that the majority of our Senate members are elected on the basis of multi-member elections. According to the law, 86 members of the upper house the Senate - are elected by the corps of deputies of local councils. Most importantly, the implementation of this Code has legally strengthened the introduction of new, advanced practices that will ensure a more transparent electoral process in our country. And it is no exaggeration to say that in the future the electoral system will be a solid foundation for improving the mechanisms for conducting democratic reforms in the country on the basis of new political requirements, strong competition between parties, the struggle of ideas and programs.

\section{REFERENCES}

1. The first Address of the President of the Republic of Uzbekistan Sh.M.Mirziyoev to the Oliy Majlis of the Republic of Uzbekistan. December 22, 2017.

2. Electoral Code of the Republic of Uzbekistan National Database of Legislation. 26.06.2019. 03/19/544/3337. 